\title{
Hatchability of gemmules of two Neotropical freshwater sponges (Porifera: Spongillida)
}

\author{
Ludimila Calheira (D), Paulo J. P. Santos (i) \& Ulisses Pinheiro
}

Departamento de Zoologia, Universidade Federal de Pernambuco, Recife, Brazil. (calheiralaurindo@gmail.com; pjp.santos@gmail.com; uspinheiro@hotmail.com)

Received 30 November 2018

Accepted 20 November 2019

Published 10 January 2020

DOI 10.1590/1678-4766e2020001

\begin{abstract}
Inland waters experience extreme environmental conditions determining the evolution of several adaptive strategies of the fauna to these variable conditions. Freshwater sponges produce resisting bodies called gemmules that contain totipotent cells and specialized spicules (gemmuloscleres). Completely formed gemmules exhibit low metabolic rates and may become dormant during periods of environmental stress. Until now, few species had their hatchability tested against different environmental conditions. The purpose of the present study was to test the capacity of hatching gemmules of two freshwater sponge species (Heteromeyenia cristalina Batista, Volkmer-Ribeiro \& Melão, 2007 and Radiospongilla inesi Nicacio \& Pinheiro, 2011) from inland waters from different localities. Five assays were tested (A): A1 (water of sponge collection site); A2 (Pirangi River water); A3 (Araraquara Pond water); A4 (mineral water) and A5 (A1 after drying gemmules). For each assay, three replicates with 30 gemmules were used. The gemmules were observed daily during 30 days. Data analysis was performed using ANOVA and a posteriori Tukey test. Results showed that gemmules from both species submitted to A3 have not hatched, probably due to its very high conductivity. There was a significant difference between assays (A1, A2 and A4) and between species $\left(\mathrm{F}_{2,12}=77.2 ; P<0.001\right)$. Comparison between $\mathrm{A} 1$ and $\mathrm{A} 5$ showed significant differences between both assays and species $\left(\mathrm{F}_{1,8}=\right.$ $27.5 ; P<0.001)$. Radiospongilla inesi presented high hatching rate at all assays, while $H$. cristalina had a high hatching rate only on A1 and A5. Results clearly show that each species has a different capacity of hatching.
\end{abstract}

KEYWORDS. Dormancy, freshwater sponges, hatching, Spongillidae.

RESUMO. Eclosão de gêmulas em duas esponjas dulciaquícolas neotropicais (Porifera: Spongillida) em diferentes águas continentais. Ambientes de águas continentais estão suscetíveis a condições ambientais extremas, determinantes à evolução de várias estratégias adaptativas para estas condições variáveis. As esponjas de águas continentais produzem corpos resistentes chamados gêmulas, que contêm células totipotentes e espículas especializadas (gemoscleras). As gêmulas completamente formadas exibem baixas taxas metabólicas e podem tornar-se dormentes tipicamente durante períodos de estresse ambiental. Até agora, poucas espécies tiveram sua capacidade de eclosão testada frente diferentes condições ambientais. O objetivo do presente estudo foi testar a capacidade de eclosão de gêmulas para duas espécies (Heteromeyenia cristalina Batista, Volkmer-Ribeiro \& Melão, 2007 e Radiospongilla inesi Nicacio \& Pinheiro, 2011) de esponjas de águas continentais em águas de diferentes localidades. Foram realizados cinco ensaios (A): A1 (água do local da coleta das esponjas); A2 (água do Rio Pirangi); A3 (água da Lagoa Araraquara); A4 (água mineral) e A5 (água do local da coleta das esponjas). Para cada ensaio, três réplicas com 30 gêmulas foram usadas. As gêmulas foram observadas diariamente durante 30 dias. A análise de dados foi conduzida usando ANOVA e o teste aposteriori Tukey. Os resultados mostraram que gêmulas de ambas espécies submetidas ao A3 não eclodiram, provavelmente devido à alta condutividade. Há diferenças entre os ensaios (A1, A2 e A4) e entre espécies $\left(\mathrm{F}_{2,12}=77.2 ; P<0.001\right)$. Ao comparar A1 e A5, houve diferenças significativas entre ambos os ensaios e espécies $\left(\mathrm{F}_{1,8}=27.5 ; P<0.001\right)$. Radiospongilla inesi apresentou alta taxa de eclosão em todos os ensaios enquanto que Heteromeyenia cristalina teve uma alta taxa de eclosão apenas no ensaio com água do seu ambiente natural. Os resultados mostram claramente que cada espécie tem diferente capacidade de eclosão.

PALAVRAS-CHAVE. Dormência, esponjas de águas continentais, eclosão, Spongillidae.

Inland waters are susceptible to extreme environmental conditions including freezing, drying or high salinity. In this sense, it is common to find several adaptive strategies of the fauna to these variable conditions. Freshwater sponges, for example, produce resisting bodies known as gemmules (Manconi \& Pronzato, 2015, 2016). These structures contain totipotent cells and specialized spicules peculiar to armed gemmules, called gemmuloscleres (MANCONI \& Pronzato, 2002, 2007, 2016).

Gemmules can be found in species belonging to three families currently placed in Spongillida (MANCONI
\& Pronzato, 2002). Potamolepidae species deposit their gemmules with a simple architecture at the sponge-substrate interface, whereas gemmules of the Spongillidae and Metaniidae are distributed throughout the sponge body and have complex gemmule morphology with a well-developed pneumatic layer, and spiny gemmuloscleres (MANCONI \& PronZato, 2007).

Completely formed gemmules exhibit low metabolic rates and may become dormant. Most freshwater sponges undergo a period of dormancy at some time during the year, typically during periods of environmental stress, 
until hatching occurs (REISWIG et al., 2009). HARRISON \& Simpson (1976) proposed that dormancy of gemmules is likely to be controlled by interactions between exogenous (e.g., temperature, light, salinity, oxygen tension, and $\mathrm{pH}$ ) and endogenous factors (e.g. concentrations of calcium, and osmotic pressure). Pronzato et al. (1993) proposed that endogenous processes are involved in the control of life cycle phases, and seasonality and length of phases are subject to exogenous limiting factors, such as ice-up and dry-up.

Stressful conditions can be crucial to the success of gemmules hatching in some species. FeLL (1987) and MELÃo \& Rocha (1996) showed that exposure of gemmules to low temperatures or drying can stimulate hatching when conditions resume later to an ideal environmental condition, respectively in the cases of Eunapius fragilis (Leidy, 1851) and Metania spinata (Carter, 1881). Gemmules of Ephydatia muelleri (Lieberkühn, 1856), Racekiela ryderii (Potts, 1882) and Spongilla lacustris (Linnaeus, 1759) also have been shown to be tolerant of low temperatures (BARBEAU et al., 1989; Fell \& BAZer, 1990; Fell \& LeVASSEUR, 1991; Fell, 1994; UNGEMACH et al., 1997). Most studies on hatchability of gemmules focused in low temperatures and drying, but FELL (1992) tested for salinity tolerance of E. fragilis's gemmules, and ReISWIG \& MiLler (1998) verified that $E$. muelleri's gemmules could survive seasonal anoxia.

Until now, few species had their hatchability tested against different environmental conditions. The purpose of this study was to test the capacity of hatching in different inland waters of the gemmules from two Neotropical freshwater sponges belonging to the Spongillidae: Heteromeyenia cristalina Batista, Volkmer-Ribeiro \& Melão, 2007 and Radiospongilla inesi Nicacio \& Pinheiro, 2011.

\section{MATERIAL AND METHODS}

Specimens of Heteromeyenia cristalina and Radiospongilla inesi were collected at fish farming tanks of Universidade Federal Rural de Pernambuco, UFRPE (08¹9'40"S, 3456’39.93”'W), fed with water from Prata River, northeast Brazil (Figs 1, 2).

Sponges were individually packed in a container with water of their own environment and transported to the laboratory. Additionally, the tank water was also collected and stored in a glass container $(6 \mathrm{~L})$. Other samples of water used in this study were all from northeast Brazil: water from Pirangi River ( $08^{\circ} 44^{\prime} 53.0^{\prime}$ 'S, $\left.35^{\circ} 48^{\prime} 51.1^{\prime \prime} \mathrm{W}\right)$, due to its high diversity of sponges, with at least four species recorded there (Pinheiro et al., 2013; Nicacio \& Pinheiro, 2015); water from Araraquara Pond ( $\left.06^{\circ} 25^{\prime} 14.1^{\prime \prime} \mathrm{S}, 34^{\circ} 59^{\prime} 19.0^{\prime \prime} \mathrm{W}\right)$, considered to be rich in organic material (humic water); and mineral water from Emerald Source, due to its purity (Tab. I). Voucher specimens of $H$. cristalina and R. inesi were deposited in Porifera Collection of the Universidade Federal de Pernambuco (UFPEPOR 1943 and UFPEPOR 1944, respectively).

Physico-chemical parameters of the water samples measured for this study were: temperature $\left({ }^{\circ} \mathrm{C}\right)$; dissolved oxygen (DO $\mathrm{mg} / \mathrm{L})$; conductivity $(\mu \mathrm{S} / \mathrm{cm}) ; \mathrm{pH}$; and
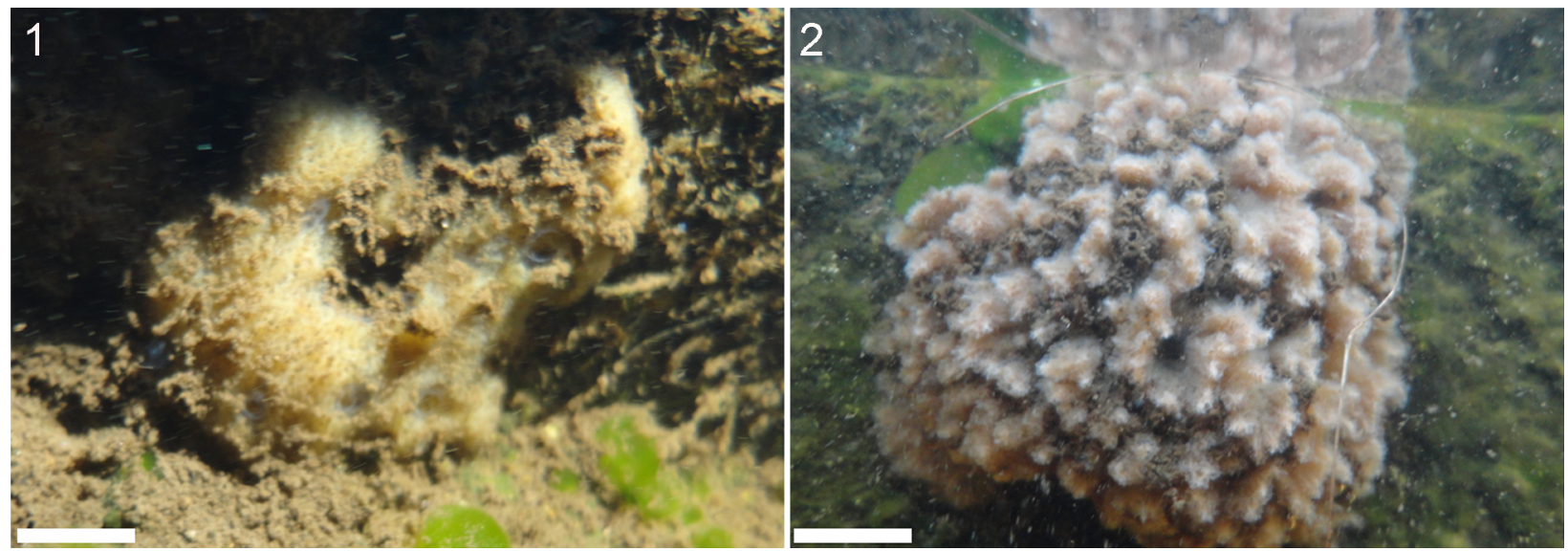

Figs 1,2. Species in situ, Recife, PE, Brazil: 1, Heteromeyenia cristalina Batista, Volkmer-Ribeiro \& Melão, 2007; 2, Radiospongilla inesi Nicacio \& Pinheiro, 2011. Scale bars $=1 \mathrm{~cm}$.

Tab. I. Physico-chemical characteristics of the waters used in the assays

\begin{tabular}{lcccccc}
\hline Waters & $\begin{array}{c}\text { Temperature } \\
\left({ }^{\circ} \mathrm{C}\right)\end{array}$ & $\begin{array}{c}\text { Dissolved Oxygen } \\
(\mathrm{DO} \mathrm{mg} / \mathrm{L})\end{array}$ & $\begin{array}{c}\text { Conductivity } \\
(\mathrm{uS} / \mathrm{cm})\end{array}$ & $\begin{array}{c}\text { Salinity } \\
(\mathrm{g} / \mathrm{L})\end{array}$ & $\begin{array}{c}\mathrm{Silica} \\
(\mathrm{Si} \mathrm{mg} / \mathrm{L})\end{array}$ \\
\hline Sponge's site collecting (A1) & 30.2 & 9.4 & 1.2 & 0.0 & 6.9 & 6.5 \\
Pirangi River (A2) & 27.5 & 8.5 & 67.9 & 0.03 & 7 & 12.1 \\
Araraquara Pond (A3) & 30.2 & 8.7 & 204.8 & 0.08 & 5.1 & 6.5 \\
Mineral water (A4) & 24.1 & 8.2 & 63.9 & 0.02 & 5.4 & 6.5 \\
A1+drying gemmules (A5) & 29.9 & 9.8 & 70 & 0.03 & 7.1 & 7.9 \\
\hline
\end{tabular}


silica concentration (SImg / L). These parameters were measured using a multiparameter (YSI-Professional Plus) and a silica concentration analyzer (Silica High Range portable photometer). Salt concentration was obtained from conductivity values.

In the laboratory, gemmules were removed from sponges and allocated in 24 well $(3 \mathrm{ml})$ plates, containing a single gemmule each, and initiated the culture at room temperature (ca., $25^{\circ} \mathrm{C}$ on average). Five assays were tested: A1 (water from the fish farming tanks where the sponges were collected); A2 (Pirangi River water); A3 (Araraquara Pond water); A4 (mineral water) and A5 (A1 + dry gemmules). Gemmules of the A5 were stored in Petri dishes covered with filter paper for 10 days to dry (FELL, 1987). After this period, gemmules were allocated to plates with water from the fish farming tanks where the sponges were collected.

For each assay, three replicates with 30 gemmules were used. The gemmules were observed daily during 30 days under a stereomicroscope to register the number of hatching gemmules and how many gemmules develop into juvenile sponges.

Factorial ANOVA was used to test for the significance of hatching average differences among different assays and between species. The a posteriori Tukey test was used to compare pairs of averages between the assays. The Bartlett test was used to test the homogeneity of variances. The significance level of $5 \%$ was adopted.

\section{RESULTS}

Gemmules of Heteromeyenia cristalina and Radiospongilla inesi did not hatch (Tab. I, Figs 3, 4) when submitted to humic waters (A3). In the other assays (A1, A2 and A4) gemmules of both species hatched (Figs 5, 6) with significant differences among assays $\left(\mathrm{F}_{2 ; 12}=83.5, P\right.$ $<0.001)$ and between species $\left(\mathrm{F}_{2 ; 12}=190.0, P<0.001\right)$.

The water of fish farming tanks (A1) yielded high rates of gemmule hatching, $92 \%$ for $H$. cristalina and $80 \%$
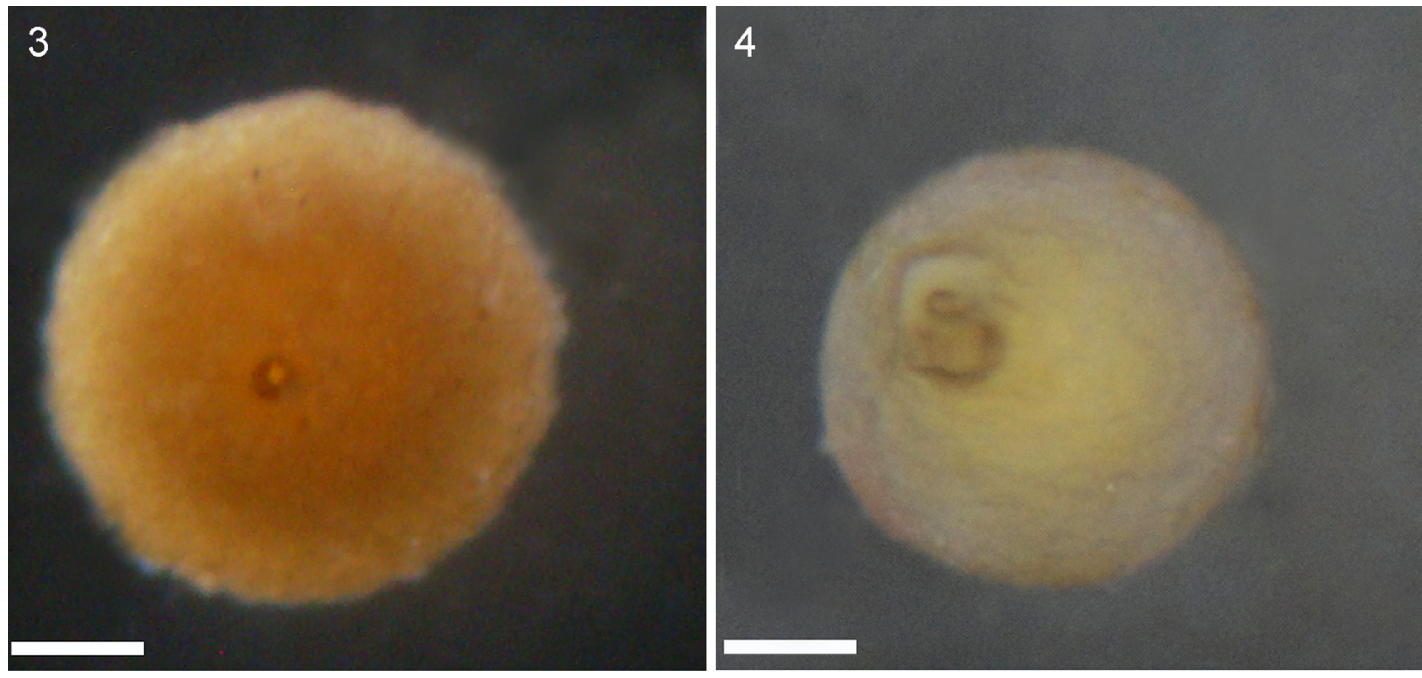

Figs 3,4. Gemmules submitted to Araraquara Pond water: 3, Heteromeyenia cristalina Batista, Volkmer-Ribeiro \& Melão, 2007; 4, Radiospongilla inesi Nicacio \& Pinheiro, 2011. Scale bars $=100 \mu \mathrm{m}$.
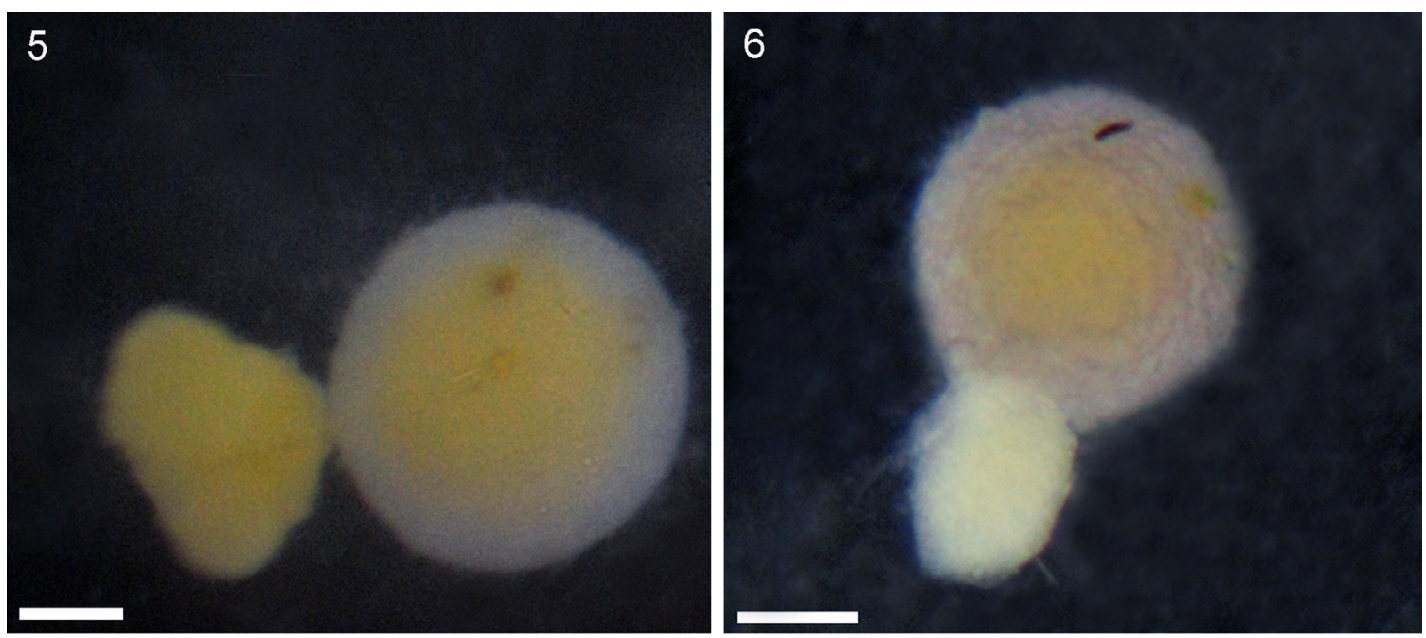

Figs 5,6. Gemmules hatching: 5, Heteromeyenia cristalina Batista, Volkmer-Ribeiro \& Melão, 2007; 6, Radiospongilla inesi Nicacio \& Pinheiro, 2011. Scale bars $=100 \mu \mathrm{m}$. 
for $R$. inesi (Fig. 7). On the other hand, gemmules of both species had different results when submitted to waters from Pirangi River (A2) and mineral water (A4). Radiospongilla inesi showed higher hatching rates with $79 \%$ and $78 \%$, against only $8 \%$ and $2 \%$ for $H$. cristalina (Fig. 7 ), respectively.

When comparing dried up gemmules (A5) results with those obtained in A1 (without drying), a different response pattern was observed $\left(\mathrm{F}_{1 ; 8}=27.5, P<0.001\right.$; Tukey test, $P=$ 0.004) (Fig. 8). Heteromeyenia cristalina showed significant differences (Tukey test, $P=0.003$ ), with $92 \%$ of gemmules hatching without drying (A1) and only $66 \%$ when exposed to drying conditions (A5); while in $R$. inesi there was no significant difference (Tukey test, $P=0.2$ ) despite a slight increase of hatching rate ( $80 \%$ in A1 and $91 \%$ in A5) (Fig. 8).

The gemmules from $R$. inesi developed sponges in all assays, with a success rate of $94 \%$ (A1), $65 \%$ (A2), 97\% (A4) and $77 \%$ (A5). Gemmules of $H$. cristalina formed sponges only in A1 (60\%) and A5 (37\%) (Figs 9-11).
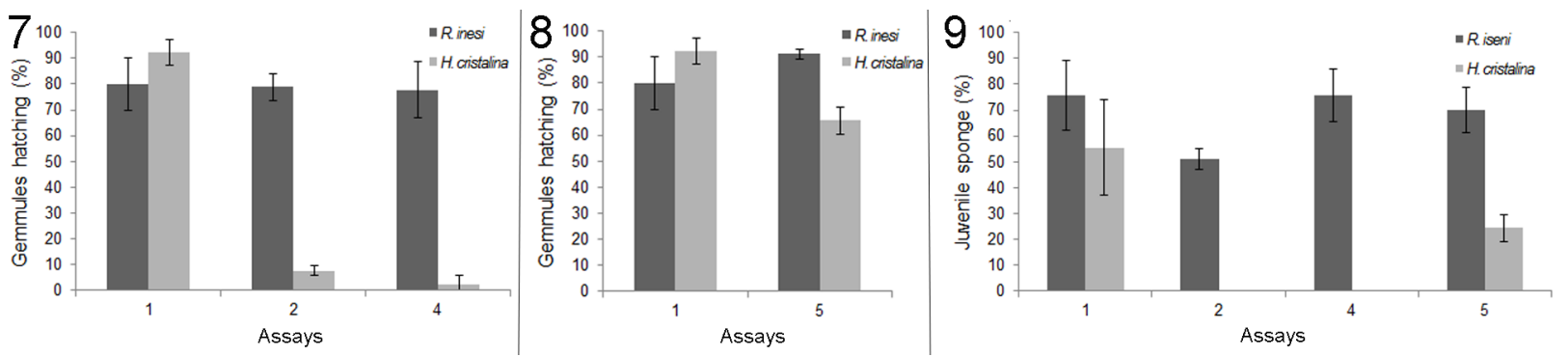

Figs 7-9. Percentage of gemmules hatching from Heteromeyenia cristalina Batista, Volkmer-Ribeiro \& Melão, 2007 and Radiospongilla inesi Nicacio \& Pinheiro, 2011. Fig. 7, Gemmules submitted to assays: A1. Water of sponge's site collecting, Recife, PE; A2. Pirangi River water, Jaqueira, PE; A4. Mineral water; Fig. 8, gemmules submitted to assays: A1. Water of sponge's site collecting, Recife, PE and A5. Water of sponge's site collecting + drying gemmules; Fig. 9, percentage of developed sponges from gemmules hatching.
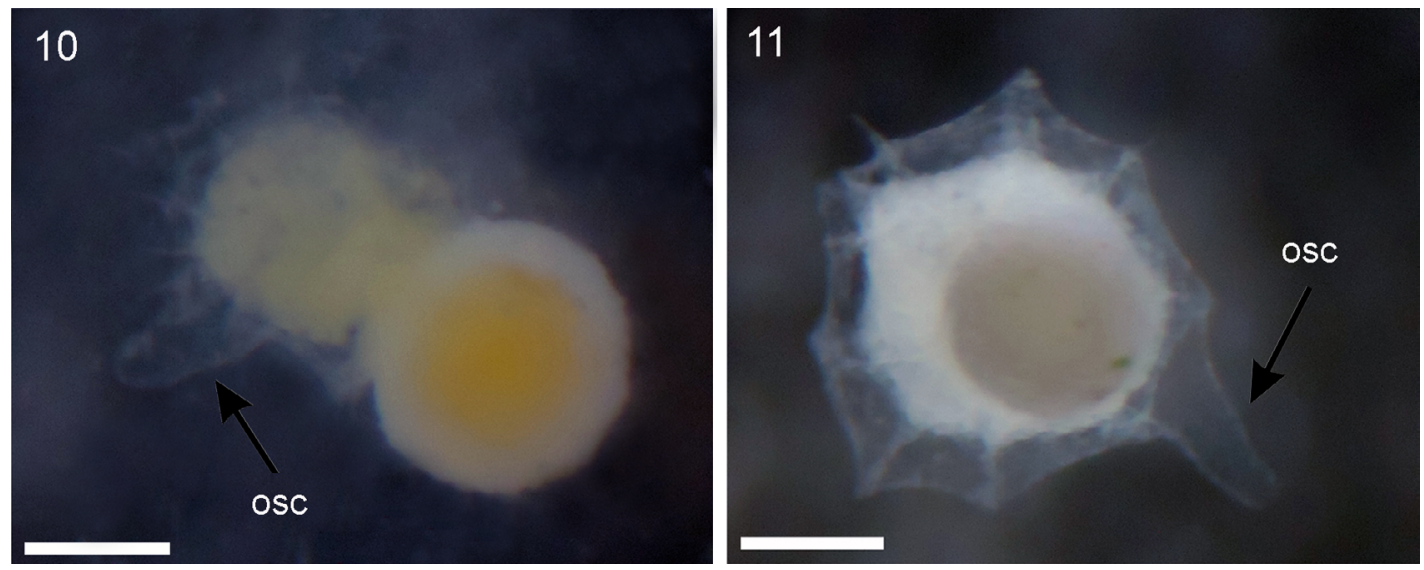

Figs 10,11. Sponges developed from gemmules hatching: 10, Heteromeyenia cristalina Batista, Volkmer-Ribeiro \& Melão, 2007; 11, Radiospongilla inesi Nicacio \& Pinheiro, 2011 (osc, oscule). Scale bars $=200 \mu \mathrm{m}$.

\section{DISCUSSION}

Gemmules of both species submitted to Araraquara Pond waters have not hatched, probably due to its conductivity that was three times higher than that of the other waters tested here (see Tab. I). The high conductivity of this environment can be explained by the organic matter enrichment. Until now, only six species from Neotropical freshwater sponges were found in humic waters: Corvomeyenia thumi (Traxler, 1895), Metania spinata (Carter, 1881), Tubella variabilis (Bonetto \& Ezcurra de Drago, 1973), Dosilia pydanieli VolkmerRibeiro, 1992, Radiospongilla amazonensis Volkmer-Ribeiro \& Maciel, 1983 and Corvomeyenia epilithosa VolkmerRibeiro, De Rosa-Barbosa \& Machado, 2005 (VoLKMERRIBEIRO, 1992; VolKMER-RIBEIRo et al., 2005). Except for the latter, the other species are not restricted to humic waters and have wide distribution, indicating adaptive plasticity to cope with different kinds of inland waters (VOLKMERRIBEIRO et al., 2005).

There were significant differences among assays (A1, A2 and A4) and between species. Radiospongilla inesi presented a high hatching rate and sponge development at all water tested, whereas $H$. cristalina had high hatching rate and sponge development only at its own collection water. Regarding $H$. cristalina, these results were completely unexpected due to its wide distribution on the Neotropical region (MURICY et al., 2011). Conversely, $R$. inesi is only known from its type locality until now (NiCACIO et al., 2011). In this sense, despite belonging to the same family and sharing a complex gemmular morphology, $H$. cristalina and $R$. inesi have different potential of adaptation to different environments due to the distinct hatchability potential of their gemmules. 
Considering the experiment with dried gemmules, $R$. inesi and $H$. cristalina showed also very different hatching capacities. This result contrasts with those obtained by MELÃo \& Rосна (1996) for Metania spinata, and by Fell (1987) for Eunapius fragilis, of increased hatching rates after drying of gemmules (Melão \& Rocha, 1996; Fell, 1987).

Our results indicate that gemmule hatching capacity and, in ultimate instance, the distribution of freshwater sponge species is not only related with gemmular morphology and/ or exposition to extreme environmental conditions. Here we tested the feasibility of hatching gemmules in distinct habitats, under laboratory conditions, but very little about their hatchability to face environmental variables with temperature, $\mathrm{pH}$, turbidity, flow energy and depth. Therefore, this study can be used as a model so future eco-physiological studies could be performed, thereby to increase our understanding of the real influence of the gemmule physiology on the distribution of species.

Acknowledgements. The authors are grateful to Ana C. S. Almeida (Universidade Federal de Pernambuco, Brazil), Daniele Mariz (Universidade Federal de Pernambuco, Brazil) and George Joaquim Garcia Santos (Universidade Federal do Cariri, Brazil) for logistical support. This study was financed in part by the Coordenação de Aperfeiçoamento de Pessoal de Nível Superior - Brasil (CAPES) - Finance Code 001. Thanks also due to Fundação de Amparo à Ciência e Tecnologia do Estado de Pernambuco (FACEPE) and Conselho Nacional de Desenvolvimento Científico e Tecnológico (CNPq) for financial support.

\section{REFERENCES}

BarbeaU, M. A.; ReIswig, H. M. \& Rath, L. C. 1989. Hatching of freshwater sponge gemmules after low temperature exposure: Ephydatia muelleri (Porifera: Spongillidae). Journal of Thermal Biology 14:225-231.

FeLL, P. E. 1987. Influences of temperature and desiccation in the gemmules of Eunapius fragilis (Leidy, 1851). Invertebrate Reproduction \& Development 11:305-315.

Fell, P. E. 1992. Salinity tolerancy of the gemmules of Eunapius fragilis (Leidy) and the inhibition of germination by various salts. Hydrobiologia 242:33-39.

FelL, P. E. 1994. Dormancy of the gemmules of Eunapius fragilis and Ephydatia muelleri in New England. In: van SOEST, R. W. M.; vaN Kempen, T. M. G. \& Braekman, J. C. eds. Sponges in Time and Space: Biology, Chemistry, Paleontology. Balkema, Rotterdam, Brookfield, p. 313-320.

FeLL, P. E. \& BAZER, L. J. 1990. Survival of the gemmules of Anheteromeyenia ryderi (Potts) following aerial exposure during winter in New England. Hydrobiologia 190:241-246.

Fell, P. E. \& Levasseur, E. D. 1991. Cold hardiness of the green gemmules of Spongilla lacustris L. (Porifera: Spongillidae). Hydrobiologia 218:107-112.
Harrison, F. W. \& Simpson, T. L. 1976. Introduction: Principles and perspectives in sponge biology. In: HARRISON, F. W. \& COWDEN, R. R. eds. Aspects of Sponge Biology. New York, Academic Press, p. 3-17.

Manconi, R. \& PronZato, R. 2002. Suborder Spongillina subord. nov.: Freshwater sponges. In: HoOPER, J. N. A \& van SOEST, R. W. M. eds. Systema Porifera: A guide to the classification of sponges. New York, Kluwer Academic/Plenum Publishers,. p. 921-1021.

Manconi, R. \& Pronzato, R. 2007. Gemmules as a key structure for the adaptive radiation of freshwater sponges: a morphofunctional and biogeographic study. In: Custódio, M. R.; HaJdu, E.; Lobo-Hadju, G. \& Muricy, G. eds. Porifera Research: Biodiversity, Innovation and Sustainability. Rio de Janeiro, Museu Nacional, p. 61-77.

Manconi, R. \& Pronzato, R. 2015. Chapter 3 Phylum Porifera. In: Thorp, J. \& Rogers, D. C. eds. Keys to Nearctic Fauna: Thorp and Covich's Freshwater Invertebrates. 4ed, Vol. II. San Diego, Academic Press, Elsevier, p. 39-83.

Manconi, R. \& Pronzato, R. 2016. How to survive and persist in temporary freshwater? Adaptive traits of sponges (Porifera: Spongillida): A review. Hydrobiologia 782:11-22.

Melão, M. G. G. \& RochA, O. 1996. Germinação de gêmulas de Metania spinata (Porifera, Metaniidae). Anais do VII Seminário Regional de Ecologia, São Carlos, SP, Brasil, 7:81-85.

Muricy, G.; Lopes, D. A.; Hajdu, E.; Carvalho, M. S.; Moraes, F. C.; Klautau, M.; Menegola, C. \& Pinheiro, U. 2011. Catalogue of Brazilian Porifera. In: Barrios, M. A. M. \& Caramaschi, U. eds. Museu Nacional, vol 46. Rio de Janeiro, Museu Nacional. 212p.

Nicacio, G. \& Pinheiro, U. 2015. Biodiversity of freshwater sponges (Porifera: Spongillina) from northeast Brazil: new species and notes on systematics. Zootaxa 3981:220-240. http://dx.doi: 10.11646/ zootaxa.3981.2.4.

NiCACIO, G.; SeVERI, W. \& PinheIRo, U. 2011. New species of Radiospongilla (Porifera: Spongillidae) from Brazilian inland waters. Zootaxa 3132:5663.

Pinheiro, U.; Docio, L.; Nicacio, G. \& Hajdu, E. 2013. A reassessment of neotropical species of Corvospongilla (Porifera: Spongillidae). Journal of Natural History 1-12. http://dx.doi: 10.1080/00222933.2013.798700.

Pronzato, R.; Manconi, R. \& Corriero, G. 1993. Biorhythm and environmental control in the life history of Ephydatia fluviatilis (Demospongiae, Spongillidae). Italian Journal of Zoology 60(1):6367.

ReISwiG, H. M. \& MiLLER, T. L. 1998. Freshwater sponge gemmules survive months of anoxia. Invertebrate Biology 117:1-8.

Reiswig, H. M.; Frost, T. M. \& Ricciardi, A. 2009. Porifera. In: ThorP, J. H. \& Covich, A. P. eds. Ecology and Classification of North American Freshwater Invertebrates. New York, Elsevier, Academic Press, p. 91-123.

Ungemach, L. F.; Souza, K.; Fell, P. E. \& Loomis, S. H. 1997. Possession and loss of cold tolerance by sponge gemmules: a comparative study. Invertebrate Biology 116:1-5.

Volkmer-Ribeiro, C. 1992. The Freshwater Sponges In Some Peat-Bog Ponds In Brazil. Amazoniana 12:317-335.

Volkmer-Ribeiro, C.; Rosa-Barbosa, R. De \& Machado, V. S. 2005. Corvomeyenia epilithosa sp. nov. (Porifera, Metaniidae) no Parque Nacional da Serra Geral, Rio Grande do Sul, Brasil. Revista Brasileira de Zoologia 22:844-852. 